\title{
New strains of Bradyrhizobium enrich plant biomass nitrogen content in Crotalaria for use as a green manure
}

\author{
Jacqueline Savana da Silva ${ }^{1}$ (D), Dâmiany Pádua Oliveira ${ }^{1}$ (D), Márcia Rufini ${ }^{1}$ (D), Celso Leandro da Silva \\ Junior $^{1}$ (D), Maria Vitória Batista Duque Guttierrez Baptista ${ }^{1}$ (D), Lourdes Cláudia da Silva ${ }^{1}$ (D), Osnar \\ Obede da Silva Aragão ${ }^{1}$ (D) Thiago de Assis Pereira ${ }^{1}$ (D), Fatima Maria de Souza Moreira ${ }^{1, \star}$ (ID $^{-}$ \\ 1. Universidade Federal de Lavras - Escola de Ciências Agrárias de Lavras - Departamento de Ciência do Solo - Lavras (MG), Brazil. \\ Received: Nov. 13, 2020 | Accepted: May 3, 2021 \\ Section Editor: Fernando César Bachiega Zambrosi \\ *Corresponding author: fmoreira@ufla.br \\ How to cite: Silva, J. S., Oliveira, D. P., Rufini, M., Silva Junior, C. L., Baptista, M. V. B. D., Silva, L. C., Aragão, O. O. S., Pereira, T. A. and Moreira, \\ F. M. S. (2021). New strains of Bradyrhizobium enrich plant biomass nitrogen content in Crotalaria for use as a green manure. Bragantia, 80 , \\ e4021. https://doi.org/10.1590/1678-4499.20200469
}

\begin{abstract}
In spite of the chemical, physical, and biological benefits that Crotalaria spectabilis can provide to the soil, it is little used as a green manure crop by farmers. Inoculation with strains of legume-nodulating nitrogen-fixing bacteria that are efficient and competitive may be a strategy to enhance accumulation of $\mathrm{N}$ in C. spectabilis and stimulate adoption of this green manure crop. The aims of this study were i) to evaluate the symbiotic and agronomic efficiency of new strains of Bradyrhizobium on C. spectabilis in an oxisol (red latosol) compared to that of noninoculated controls (without and with mineral N) and with the approved strain BR2811, seeking to corroborate possible recommendation as inoculants for this species; and ii) to determine, the contribution of these treatments to $\mathrm{N}$ accumulation in the plant of $C$. spectabilis in four periods of cutting for determining possible and ideal periods for its incorporation in the soil. Experiments were carried out in pots and field. Inoculation with the new strains UFLA05-03, UFLA05-09, and UFLA05-14 and with BR2811 on C. spectabilis is effective since it increases the production of N-enriched plant biomass when compared to the control without N mineral. However, UFLA0503 stands out among these strains because it behaves similarly to the control with mineral $\mathrm{N}$ both in relation to shoot $\mathrm{N}$ accumulation and dry matter just after 150 days in the field.
\end{abstract}

Key words: Crotalaria spectabilis, nodulating nitrogen-fixing bacteria, legume species inoculant, strain selection.

\section{INTRODUCTION}

Green manure is able to increase the productive capacity of soils in a sustainable manner, since it improves the soil physical, chemical, and biological characteristics (Aita et al. 2001; Aita and Giacomini 2003; Mercante et al. 2014; Moreira and Siqueira 2006). Among the plant species most used for this practice is Crotalaria spectabilis, a Leguminosae that arose in South and North America, whose excellent production of fresh matter (15 to $\left.30 \mathrm{t} \cdot h \mathrm{a}^{-1}\right)$, dry matter ( 3 to $\left.8 \mathrm{t} \cdot \mathrm{ha}^{-1}\right)$, and estimated N (100 to $160 \mathrm{~kg} \cdot \mathrm{ha}^{-1}$ ) lead to increases of up to 100\% in the yield of successive crops (Albuquerque et al. 2013; Nogueira et al. 2019; Souza et al. 2008; Tenelli et al. 2019). The mean flowering period of this species is 120 days, which can be a limiting factor for its use as a green manure crop on the part of producers who do not have that much time between crop seasons. However, it can be used intercropped with other species. For instance, Mendonça et al. (2017) evaluated N dynamics in intercropping between C. spectabilis and coffee and found that, of the total of $\mathrm{N}$ accumulated ( $93.42 \mathrm{~kg} \cdot \mathrm{ha}^{-1}$ ) in the soil, $34.10 \mathrm{~kg} \cdot \mathrm{ha}^{-1}$ was derived from biological nitrogen fixation (BNF), and $48.8 \%$ of the $\mathrm{N}$ originating from BNF was transferred to the coffee plants.

The symbiosis of C. spectabilis with legume nodulating $\mathrm{N}_{2}$ - fixing bacteria (LNNFB) can provide numerous benefits to plant production (Moreira and Siqueira 2006). Resende et al. (2003) showed that more than $80 \%$ of the N in C. spectabilis can originate from BNF. However, these benefits can be improved if highly efficient strains are used in its cultivation. 
Studies on selection of strains efficient in BNF for C. spectabilis are few and are limited to only axenic conditions (Florentino et al. 2014; Rangel et al. 2017). However, promising results in relation to the symbiotic efficiency of Bradyrhizobium strains with C. spectabilis under axenic conditions indicate that their biotechnological potential should be determined under field conditions (Rangel et al. 2017).

Currently, there are only two strains approved by the Brazilian Ministry of Agriculture (MAPA, Ministério da Agricultura, Pecuária e Abastecimento) as inoculants for C. spectabilis, both belonging to the genus Bradyrhizobium: BR2003/SEMIA6156 (B. japonicum) and BR2811/SEMIA6158 (B. elkanii). However, the absence of publications that corroborate this recommendation generates questions regarding the criteria adopted in the recommendation process, which, according to MAPA, was restricted to tests in pots with soil (Brazil 2011). In addition, diverse environmental factors and traits of the symbionts can affect success in symbiosis. Therefore, in selection studies, the LNNFB strains must be tested in regard to their efficiency in fixing $\mathrm{N}_{2}$ and their competitiveness for infection sites against native microorganisms under diverse edaphic and climatic conditions in the field, with the aim of obtaining suitable inoculants (Moreira and Siqueira 2006).

Given the diverse advantages of the use of $C$. spectabilis as a green manure crop, the lack of articles published on its symbiosis with LNNFB, and lack of information on the best time for cutting and incorporation related to $\mathrm{N}$ accumulation in the plant biomass, the hypothesis that $C$. spectabilis benefits from BNF and that its inoculation with new efficient strains of LNNFB will increase the accumulation of $\mathrm{N}$ by the plant was worked with.

Thus, the aims of this study were i) to evaluate the symbiotic and agronomic efficiency of inoculation of three strains of Bradyrhizobium on C. spectabilis in an oxisol (red latosol) compared to that of noninoculated controls (without and with mineral N) and with the approved strain BR2811, seeking to corroborate possible recommendation as inoculants for this species; and ii) to determine, the contribution of these treatments to $\mathrm{N}$ accumulation in the plant biomass of C. spectabilis in four periods of cutting for determining possible and ideal periods for its incorporation in the soil.

\section{MATERIALS AND METHODS}

Three experiments with C. spectabilis for use as a green manure crop were performed from October 2017 to April 2018. The first experiment was conducted to estimate the density of the native populations of nodulating nitrogen-fixing bacteria of C. spectabilis in the soil of an experimental area of the Universidade Federal de Lavras, Lavras, MG, Brazil, from which the soil for the experiment in pots was taken and where the field experiment was conducted. The latter two experiments were conducted with the aim of evaluating the symbiotic and agronomic efficiency of the LNNFB, previously selected as based on good results in axenic study (Rangel et al. 2017).

The soil used was classified as an oxisol (red latosol) of known fertility (Table 1) in an area with a history of growing grasses and noninoculated common bean.

\section{Most probable number (MPN) of LNNFB in the soil of the experiment}

For estimation of the native populations of LNNFB present in the soil of the experiment, the most probable number (MPN) method was used. Before the field experiment was set up, soil samples were collected from five points of the experimental area in the $0-20 \mathrm{~cm}$ layer to compose a single sample that was used for serial dilutions in decimal form. The experiment was conducted in a greenhouse in a completely randomized design, with three replications, using long neck dark bottles with $500 \mathrm{~mL}$ capacity containing sterilized Hoagland and Arnon (1950) nutrient solution. Before planting, the C. spectabilis seeds were scarified in $98 \%$ sulfuric acid for 5 min (Rangel et al. 2017), washed successively in sterilized distilled water, and left to soak for $20 \mathrm{~min}$. After that, they were pregerminated in sterilized Petri dishes containing moistened cotton and incubated for two days at a temperature of $28^{\circ} \mathrm{C}$. After planting, the pregerminated seeds were inoculated with $1 \mathrm{~mL}$ of the soil suspensions from the serial dilutions from $10^{-1}$ to $10^{-6}$. A positive control was included with the strain BR2811 
approved by MAPA for C. spectabilis, as well as two negative controls without inoculation (one with $5.25 \mathrm{mg} \cdot \mathrm{L}^{-1}$ and the other with $52.5 \mathrm{mg} \cdot \mathrm{L}^{-1}$ of mineral $\mathrm{N}$ ).

The experiment was conducted at a mean temperature of $23.6^{\circ} \mathrm{C}$ and $73 \%$ relative humidity. The plants were collected at 30 days after planting, at which time root nodulation was evaluated considering the presence or absence of nodules in each dilution.

Table 1. Chemical and physical properties of soil samples, taken at the $0.00-0.20 \mathrm{~m}$ depth layer, and geographic coordinates of the experimental area in Lavras-MG.

\begin{tabular}{|c|c|c|c|}
\hline \multirow{2}{*}{ Characteristics $^{1}$} & & \multicolumn{2}{|c|}{ Results } \\
\hline & & Oxisol & Interpretation ${ }^{2}$ \\
\hline $\mathrm{pH} \mathrm{H}_{2} \mathrm{O}(1: 2.5)$ & - & 6.00 & M \\
\hline $\mathrm{P}$ & $\mathrm{mg} \cdot \mathrm{dm}^{-3}$ & 28.51 & VG \\
\hline $\mathrm{K}$ & $\mathrm{mg} \cdot \mathrm{dm}^{-3}$ & 136.20 & VG \\
\hline $\mathrm{Ca}$ & $\mathrm{cmol}_{\mathrm{c}} \cdot \mathrm{dm}^{-3}$ & 2.38 & M \\
\hline $\mathrm{Mg}$ & $\mathrm{cmol}_{\mathrm{c}} \cdot \mathrm{dm}^{-3}$ & 0.92 & G \\
\hline $\mathrm{Al}$ & $\mathrm{cmol} \cdot \mathrm{dm}^{-3}$ & 0.06 & VL \\
\hline $\mathrm{H}+\mathrm{Al}$ & $\mathrm{cmol}_{\mathrm{c}} \cdot \mathrm{dm}^{-3}$ & 2.45 & L \\
\hline SB & $\mathrm{cmol} \cdot \mathrm{dm}^{-3}$ & 3.65 & G \\
\hline $\mathrm{T}$ & $\mathrm{cmol}_{\mathrm{c}} \cdot \mathrm{dm}^{-3}$ & 6.10 & $M$ \\
\hline $\mathrm{t}$ & $\mathrm{cmol}_{\mathrm{c}} \cdot \mathrm{dm}^{-3}$ & 3.71 & $M$ \\
\hline $\mathrm{m}$ & $\%$ & 1.62 & $\mathrm{VL}$ \\
\hline V & $\%$ & 59.82 & M \\
\hline Organic matter & $\mathrm{dag} \cdot \mathrm{kg}^{-1}$ & 1.88 & $M$ \\
\hline Sand & $\mathrm{g} \cdot \mathrm{kg}^{-1}$ & 520 & CS \\
\hline Silt & $\mathrm{g} \cdot \mathrm{kg}^{-1}$ & 100 & CS \\
\hline Clay & $\mathrm{g} \cdot \mathrm{kg}^{-1}$ & 380 & CS \\
\hline Geographic coordinates & & & \\
\hline Altitude & $920 \mathrm{~m}$ & & \\
\hline
\end{tabular}

${ }^{1} \mathrm{pH}$ in water (v/v 1:2.5); $\mathrm{P}$ and $\mathrm{K}$ : extractor Mehlich ${ }^{-1} ; \mathrm{Ca}, \mathrm{Mg}$, Al: extractor $1 \mathrm{~mol} \cdot \mathrm{L}^{-1} \mathrm{KCl} ; \mathrm{H}+\mathrm{Al}$ : potential acidity, extracted by calcium acetate $0.5 \mathrm{~mol} \cdot \mathrm{L}^{-1}$ at pH 7. SB: sum of bases; T: cation exchange capacity at $\mathrm{pH} 7$; t: cation exchange capacity; m: aluminum saturation; V: base saturation; OM: organic matter, WalkleyBlack method; sand, silt, and clay: pipette method. ${ }^{2}$ CS: clayey soil, G: good; L: low; M: medium; VG: very good; VL: very low (according to Alvarez et al. 1999).

\section{Symbiotic efficiency of LNNFB}

The experiments to evaluate the symbiotic efficiency of the LNNFB were conducted in pots with soil and in the field. In the two experiments, three strains of Bradyrhizobium (UFLA05-03, UFLA05-09, and UFLA05-14) that proved to be efficient in previous study (Rangel et al. 2017), and the strain Bradyrhizobium BR2811 (strain approved by MAPA for C. spectabilis) were tested, as well as two noninoculated controls, without mineral N (W0N) and with mineral $\mathrm{N}(\mathrm{WN})$. The inoculants were prepared in liquid 79 medium at $28{ }^{\circ} \mathrm{C}$ and constant shaking $(110 \mathrm{rpm})$ for $96 \mathrm{~h}$ (log phase of the bacterial growth). For field experiments, the inoculum was transferred to turf sterilized in an autoclave at the proportion of 3:2(w:v) of turf and inoculum. The quality of the inoculants was monitored by counting the number of colony-forming units (CFU), respecting the minimum legal number of $10^{9}$ per $\mathrm{mL}$ (pots) or $g$ (field) of inoculant. The mean rainfall and temperature during the growing period are shown in Fig. 1. 


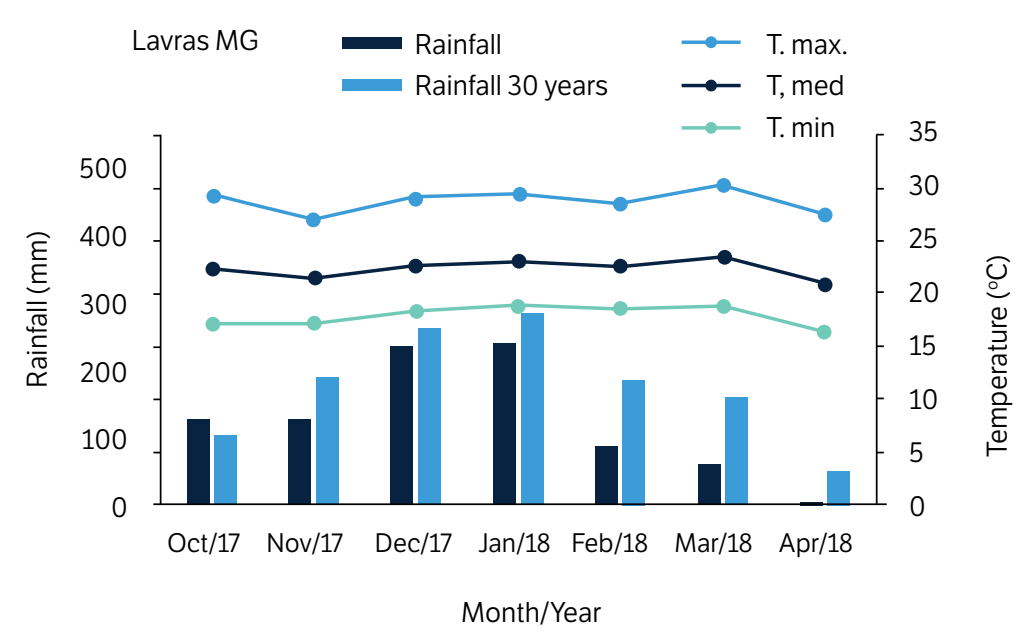

Figure 1. Monthly variation of maximum, mean and minimum temperatures and rainfall during the period of conducting the experiments and the average of the last 30 years. The pot experiment lasted from October 2017 to March 2018 and the field experiment from November 2017 to April 2018.

\section{Experiment in pots with non-sterile soil}

The experiment was conducted in a greenhouse in the period from October 2017 to March 2018. A randomized block experimental design was used with four replications for each one of the two periods of evaluation. The plants were grown in $3 \mathrm{dm}^{3}$ pots (evaluated at 60 days after sowing [DAS]) and in $5 \mathrm{dm}^{3}$ pots (evaluation at flowering at 140 DAS). The soil used for filling the pots was collected from the tillable layer $(0-20 \mathrm{~cm})$; clods were broken up, and the soil was homogenized and sieved through a $4 \mathrm{~mm}$ mesh size.

The fertilization adopted in the pots in all six treatments (element, quantity in $\mathrm{mg}_{\mathrm{dm}} \mathrm{d}^{-3}: \mathrm{P}, 300 ; \mathrm{K}, 200 ; \mathrm{Ca}, 200 ; \mathrm{Mg}, 50$; $\mathrm{S}, 50 ; \mathrm{B}, 0.8 ; \mathrm{Cu}, 1.5 ; \mathrm{Fe}, 2 ; \mathrm{Mn}, 3 ; \mathrm{Mo}, 0.10$; and $\mathrm{Zn}, 4)$ followed the recommendations of Malavolta et al. (1989). The soluble sources used were calcium phosphate monobasic (monohydrate) $\mathrm{Ca}\left(\mathrm{H}_{2} \mathrm{PO}_{4}\right) 2 \cdot \mathrm{H}_{2} \mathrm{O}$; potassium chloride $\mathrm{KCl}$; magnesium sulfate heptahydrate $\left(\mathrm{MgSO}_{4}\right) \cdot 7 \mathrm{H}_{2} \mathrm{O}$; boric acid $\mathrm{H}_{3} \mathrm{BO}_{3}$; copper sulfate pentahydrate $\left(\mathrm{CuSO}_{4}\right) \cdot 5 \mathrm{H}_{2} \mathrm{O}$; iron (III) chloride $\mathrm{FeCl}_{3}$; manganese chloride tetrahydrate $\left(\mathrm{MnCl}_{2}\right) \cdot 4 \mathrm{H}_{2} \mathrm{O}$; sodium molybdate dihydrate $\left(\mathrm{Na}_{2} \mathrm{MoO}_{4}\right) \cdot 2 \mathrm{H}_{2} \mathrm{O}$; and zinc sulfate heptahydrate $\left(\mathrm{ZnSO}_{4}\right) \cdot 7 \mathrm{H}_{2} \mathrm{O}$. The control treatment without inoculation and with mineral N received $300 \mathrm{mg} \cdot \mathrm{NH}_{4} \mathrm{NO}_{3} \cdot \mathrm{dm}^{-3}$, divided into three applications (at planting and at 10 and 20 DAS).

Preparation of the seeds followed the same procedure adopted in 2.1 (MPN). Four seeds were sown per pot and, at five days after emergence (DAE), the plants were thinned, leaving two seedlings per pot. In the treatments with bacterial strains, each seed received $1 \mathrm{~mL}$ of inoculant.

The pots were irrigated daily to maintain soil moisture near field capacity ( $60 \%$ of total pore volume). The mean values of minimum and maximum temperatures registered during the period of conducting the experiment were 19.4 and $31.5^{\circ} \mathrm{C}$, respectively.

Collections of the experiment in pots with soil occurred at 60 and 140 DAS. For each period of evaluation, all the plants from each plot (two plants per pot) were collected, considering the four replications of each treatment. The following determinations were made: number of nodules (NN), nodule dry matter (NDM), shoot dry matter (SDM), shoot $\mathrm{N}$ content (SNC) and shoot $\mathrm{N}$ accumulation (SNA). To obtain the NDM and SDM, the nodules and shoots were placed in a forced air circulation laboratory oven at $60^{\circ} \mathrm{C}$ until obtaining constant weight. The SNC was determined by the semimicro Kjeldahl (total nitrogen) method (Sarruge and Haag 1979). The SNA was calculated by multiplying the SDM by the SNC and dividing by 100.

\section{Field experiment}

The field experiment was conducted in the rainy crop season (November 2017 to April 2018) so to evaluate growth parameters of C. spectabilis in different times. A split-plot in time arrangement was adopted, consisting of four 
collection times (60,90,120 and 150 DAS) in each one of the six treatments already described, with four replications for each split treatment.

Each experimental unit $\left(10.8 \mathrm{~m}^{2}\right)$ was constituted by four $4.5 \mathrm{~m}$ rows, spaced at $0.6 \mathrm{~m}$, and the center rows were used for data collection. Soil tillage consisted of plowing, disking, and furrowing for demarcation of the rows. None of the plots received base fertilization since this is not a common practice for green manure crops in the region. The mineral nitrogen control treatment $(\mathrm{WN})$ received $70 \mathrm{~kg} \cdot \mathrm{N}$-urea $\cdot \mathrm{ha}^{-1}$, applying half at sowing and the other half in side dressing at $20 \mathrm{DAE}$.

Seeds were sown manually immediately after seed inoculation, adopting the density of 35 seeds per linear meter (Peche Filho et al. 2014). Weeds were controlled by manually weeding and ants were controlled by ant bait whenever necessary. No other control of pests or diseases was necessary.

A five-plant sample per split-plot was collected in the central rows (2-3), randomly, in each collection period for determination of NN, NDM, SDM, SNC and SNA. The methods of these evaluations followed those described in the experiments in pots with soil. For calculation of SDM e SNA in th ha ${ }^{-1}$ and $\mathrm{kg} \cdot \mathrm{ha}^{-1}$, respectively, the expected stand of 437,500 plants.ha ${ }^{-1}$ was used.

\section{Statistical analyses}

Evaluation of population density of native LNNFB was interpreted according to the table of McCrady (Döbereiner et al. 1995). Analysis of variance was carried out on the data from the two efficiency experiments after the tests of normality (Shapiro-Wilk), homoscedasticity of variances (Breusch-Pagan), and independence (Durbin-Watson) had first been carried out on the data on the R software (R Development Core Team 2019). To fulfill the presuppositions of analysis of variance, the data of all the variables were first transformed into $\log (\mathrm{y})$. When there was a significant effect by the F test ( $<<0.05$ or $\mathrm{p}<0.10$ [Brazil 2011]), the mean values of the treatments (strains tested) were contrasted with those of the controls of each trial (WN, W0N and BR2811) by Dunnett's test at the same level of significance. Controls were also evaluated between them.

\section{RESULTS}

\section{Evaluation of the density of native populations of LNNFB}

The native community of LNNFB in the soil of the experiment (used in trials in pots with soil and in the field) able to nodulate C. spectabilis was $2.5 \times 10^{3}$ cells per gram of soil.

\section{Evaluation of symbiotic efficiency in pots with non-sterile soil}

There was a significant effect of the treatments at 60 DAS, being the mean values and the contrast presented in Tables 2 and 3, respectively. There was no significant difference for NN between the treatments tested. For NDM, the UFLA05-03 strain exhibited mean similar to that of BR2811 and superior to that of the W0N and WN controls. The mean of the UFLA05-09 strain exceeded only the mean value of WN, and was similar to that of the other controls. The mean of the UFLA05-14 strain did not differ from that of the WN or W0N controls, and also did not differ from that of the BR2811 strain. There was no difference between the mean values of W0N and of the other controls, and BR2811 exceeded the results of WN. For SDM, the new strains UFLA05-03, UFLA05-09 and UFLA05-14 did not differ from controls. The BR2811 strain did not differ from W0N and both were lower than WN. For SNA, the UFLA05-03 strain had a mean value higher than that of the W0N control and of the BR2811 strain, with values statistically similar to that of the WN treatment. The mean values obtained by the UFLA05-09 and UFLA05-14 strains did not differ from those of the WN, W0N or BR2811 controls. The BR2811 did not differ from W0N, and both were lower than WN. 
Table 2. Mean values for number of nodules (NN), nodule dry matter (NDM), shoot dry matter (SDM) and shoot N accumulation (SNA) of C. spectabilis cultivated in pots with non-sterile soil (greenhouse), at $60 \mathrm{DAS}$.

\begin{tabular}{|c|c|c|c|c|}
\hline Treatments $^{1}$ & NN (unit·plant ${ }^{-1}$ ) & NDM $\left(\mathrm{mg} \cdot\right.$ plant $\left.^{-1}\right)$ & SDM $\left(g \cdot\right.$ plant $\left.^{-1}\right)$ & SNA $\left(\mathrm{mg} \cdot\right.$ plant $\left.^{-1}\right)$ \\
\hline BR2811 & 473.75 & 287.00 & 11.16 & 309.22 \\
\hline WN & 241.34 & 107.12 & 19.15 & 522.57 \\
\hline WON & 188.75 & 175.50 & 11.15 & 297.21 \\
\hline UFLA05-03 & 243.00 & 468.37 & 13.44 & 477.35 \\
\hline UFLA05-09 & 352.87 & 281.00 & 11.39 & 402.58 \\
\hline UFLA05-14 & 214.10 & 280.75 & 11.82 & 352.19 \\
\hline CV(\%) & 29.08 & 9.06 & 6.45 & 4.16 \\
\hline
\end{tabular}

${ }^{1}$ UFLA05-03, UFLA05-09, UFLA05-14 and BR2811: strains tested; WN: noninoculated control with mineral N (300 mg. $\mathrm{dm}^{-3}$ of $\mathrm{NH}_{4} \mathrm{NO}_{3}$ ); WON: noninoculated control without mineral $\mathrm{N}$.

Table 3. Contrast of mean values for number of nodules (NN), nodule dry matter (NDM), shoot dry matter (SDM) and shoot N accumulation (SNA) of $C$. spectabilis cultivated in pots with non-sterile soil (greenhouse), at 60 DAS.

\begin{tabular}{|c|c|c|c|c|c|c|c|}
\hline \multicolumn{2}{|c|}{ NN } & \multicolumn{2}{|c|}{ NDM } & \multicolumn{2}{|c|}{ SDM } & \multicolumn{2}{|c|}{ SNA } \\
\hline BR2811 & WN & BR2811* & WN & BR2811 & $W N^{\star \star}$ & BR2811 & $W^{\star * *}$ \\
\hline BR2811 & WON & BR2811 & WON & BR2811 & WON & BR2811 & WON \\
\hline WN & WON & WN & WON & $W N^{\star *}$ & WON & $W N^{\star \star}$ & WON \\
\hline UFLA0503 & BR2811 & U0503 & BR2811 & UFLA0503 & BR2811 & UFLA0503** & BR2811 \\
\hline UFLA0503 & WN & U0503** & WN & UFLA0503 & WN & UFLA0503 & WN \\
\hline UFLA0503 & WON & U0503* & WON & UFLA0503 & WON & UFLA0503** & WON \\
\hline UFLA0509 & BR2811 & U0509 & BR2811 & UFLA0509 & BR2811 & UFLA0509 & BR2811 \\
\hline UFLA0509 & WN & U0509* & WN & UFLA0509 & WN & UFLA0509 & WN \\
\hline UFLA0509 & WON & U0509 & WON & UFLA0509 & WON & UFLA0509 & WON \\
\hline UFLA0514 & BR2811 & U0514 & BR2811 & UFLA0514 & BR2811 & UFLA0514 & BR2811 \\
\hline UFLA0514 & WN & U0514 & WN & UFLA0514 & WN & UFLA0514 & WN \\
\hline UFLA0514 & WON & U0514 & WON & UFLA0514 & WON & UFLA0514 & WON \\
\hline
\end{tabular}

The treatments are compared by pairs on the line within each analyzed variable. The presence of asteristics in the treatment represents it is significantly greater than the constrating treatment ( $F$ test $[\mathrm{p}<0.05$ or $\mathrm{p}<0.10]$ ); ${ }^{* \star}$ significant effect at $5 \%$ probability; ${ }^{*}$ significant effect at $10 \%$ probability. WN: noninoculated control with mineral $\mathrm{N}\left(300 \mathrm{mg} \cdot \mathrm{dm}^{-3}\right.$ of $\left.\mathrm{NH}_{4} \mathrm{NO}_{3}\right)$; WON: noninoculated control without mineral $\mathrm{N}$.

In collection of plants at flowering ( $140 \mathrm{DAS})$, there was significant difference among the treatments only for the variables NN and NDM (Tables 4 and 5). The NN obtained from the UFLA05-14 strain exceeded that from WN and did not differ statistically from that of the other controls. For NN, the results of BR2811 exceeded the results of WN, and the results of W0N did not differ from the other controls. The NDM of the strain UFLA05-14 exhibited a mean value superior to that of the native LNNFB (WON) and did not differ from that of the other controls evaluated. The UFLA05-03 strain had a lower mean value than that of the BR2811 strain and did not differ from the mean values of the other controls. Furthermore, for NDM, there was no significant difference between the WN and BR2811 controls, and both were higher than the results of W0N.

Table 4. Mean values for number of nodules (NN), nodule dry matter (NDM), shoot dry matter (SDM) and shoot N accumulation (NAS) of C. spectabilis cultivated in pots with non-sterile soil (greenhouse), at 140 DAS.

\begin{tabular}{|c|c|c|c|c|}
\hline Treatments $^{1}$ & NN (unit $\cdot$ plant $^{-1}$ ) & NDM (mg $\cdot$ plant $^{-1}$ ) & SDM (g.plant $\left.{ }^{-1}\right)$ & SNA $\left(\mathrm{mg} \cdot\right.$ plant $\left.^{-1}\right)$ \\
\hline BR2811 & 621.37 & 1948.50 & 144.16 & 3493.16 \\
\hline WN & 144.87 & 1725.75 & 144.41 & 4205.92 \\
\hline WON & 389.50 & 624.50 & 109.95 & 2876.00 \\
\hline UFLA05-03 & 189.75 & 719.25 & 135.84 & 3460.61 \\
\hline UFLA05-09 & 409.37 & 886.25 & 144.11 & 3948.54 \\
\hline UFLA05-14 & 978.62 & 1981.12 & 138.57 & 4151.63 \\
\hline $\mathrm{CV}(\%)$ & 11.30 & 6.34 & 6.37 & 3.80 \\
\hline
\end{tabular}

${ }^{1}$ UFLA05-03, UFLA05-09, UFLA05-14 and BR2811: strains tested; WN: noninoculated control with mineral N (300 mg $\cdot \mathrm{dm}^{-3}$ of $\mathrm{NH}_{4} \mathrm{NO}_{3}$ ); WON: noninoculated control without mineral $\mathrm{N}$. 
Table 5. Contrast of mean values for number of nodules (NN), nodule dry matter (NDM), shoot dry matter (SDM) and shoot N accumulation (NAS) of $C$. spectabilis cultivated in pots with non-sterile soil (greenhouse), at 140 DAS.

\begin{tabular}{|c|c|c|c|c|c|c|c|}
\hline \multicolumn{2}{|c|}{ NN } & \multicolumn{2}{|c|}{ NDM } & \multicolumn{2}{|c|}{ SDM } & \multicolumn{2}{|c|}{ SNA } \\
\hline BR2811** & WN & BR2811 & WN & BR2811 & WN & BR2811 & WN \\
\hline BR2811 & WON & BR2811** & WON & BR2811 & WON & BR2811 & WON \\
\hline WN & WON & $W^{\star \star \star}$ & WON & WN & WON & WN & WON \\
\hline UFLA0503 & BR2811 & U0503 & BR2811* & UFLA0503 & BR2811 & UFLA0503 & BR2811 \\
\hline UFLA0503 & WN & U0503 & WN & UFLA0503 & WN & UFLA0503 & WN \\
\hline UFLA0503 & WON & U0503 & WON & UFLA0503 & WON & UFLA0503 & WON \\
\hline UFLA0509 & BR2811 & U0509 & BR2811 & UFLA0509 & BR2811 & UFLA0509 & BR2811 \\
\hline UFLA0509 & WN & U0509 & WN & UFLA0509 & WN & UFLA0509 & WN \\
\hline UFLA0509 & WON & U0509 & WON & UFLA0509 & WON & UFLA0509 & WON \\
\hline UFLA0514 & BR2811 & U0514 & BR2811 & UFLA0514 & BR2811 & UFLA0514 & BR2811 \\
\hline UFLA0514** & WN & U0514 & WN & UFLA0514 & WN & UFLA0514 & WN \\
\hline UFLA0514 & WON & U0514*^ & WON & UFLA0514 & WON & UFLA0514 & WON \\
\hline
\end{tabular}

The treatments are compared by pairs on the line within each analyzed variable. The presence of asteristics in the treatment represents it is significantly greater than the constrating treatment ( $F$ test $[p<0.05$ or $p<0.10]$ ); ${ }^{* *}$ significant effect at $5 \%$ probability; ${ }^{*}$ significant effect at $10 \%$ probability. WN: noninoculated control with mineral $\mathrm{N}\left(300 \mathrm{mg} \cdot \mathrm{dm}^{-3}\right.$ of $\mathrm{NH}_{4} \mathrm{NO}_{3}$ ); WON: noninoculated control without mineral $\mathrm{N}$.

\section{Evaluation of agronomic efficiency in the field}

The effect of the treatments on SDM and SNA depended on the time of collection, with significant differences occurring in the collections carried out at 60 and 150 DAS (Tables 6-8). At 60 DAS for SDM, the UFLA05-03 strain exceeded W0N and BR2811, but not WN control; the UFLA05-09 strain had a mean value similar to those of the controls W0N and BR2811, but was lower than that of the WN control; and the UFLA05-14 strain had a mean value lower than those of all the controls evaluated. The WN control was higher than the mean values of the other controls; BR2811 was similar to W0N. At 150 DAS (full flowering), the strains UFLA05-03 and UFLA05-14 had mean SDM values higher than those of the three controls; the UFLA05-09 strain was higher than the W0N control, and was similar to the other controls. The BR2811 and WN did not differ from each other, both were higher than the mean values of W0N.

Table 6. Mean values of shoot dry matter (SDM) and shoot $\mathrm{N}$ accumulation (SNA) of $C$. spectabilis cultivated in conventional planting area, evaluated at $60,90,120$ and 150 DAS.

\begin{tabular}{|c|c|c|c|c|}
\hline Treatments $^{1}$ & $\operatorname{SDM}\left(\mathrm{t} \cdot h \mathrm{a}^{-1}\right)$ & SDM (g.plant $\left.{ }^{-1}\right)$ & SNA $\left(k g \cdot h a^{-1}\right)$ & SNA $\left(\mathrm{mg} \cdot\right.$ plant $\left.^{-1}\right)$ \\
\hline \multicolumn{5}{|c|}{60 DAS } \\
\hline BR2811 & 2.07 & 4.73 & 84.69 & 193.58 \\
\hline WN & 3.40 & 7.78 & 133.00 & 304.00 \\
\hline WON & 2.24 & 5.13 & 81.67 & 186.67 \\
\hline UFLA05-03 & 2.77 & 6.34 & 97.45 & 222.74 \\
\hline UFLA05-09 & 2.22 & 5.07 & 83.85 & 191.67 \\
\hline UFLA05-14 & 1.74 & 3.98 & 66.44 & 151.87 \\
\hline \multicolumn{5}{|c|}{90 DAS } \\
\hline BR2811 & 7.15 & 16.35 & 317.23 & 725.09 \\
\hline WN & 5.78 & 13.21 & 205.86 & 470.53 \\
\hline WON & 5.49 & 12.56 & 174.62 & 399.13 \\
\hline UFLA05-03 & 7.64 & 17.46 & 231.36 & 528.82 \\
\hline UFLA05-09 & 6.72 & 15.37 & 232.27 & 530.91 \\
\hline UFLA05-14 & 5.91 & 13.52 & 161.72 & 369.65 \\
\hline
\end{tabular}


Table 6. Continuation...

\begin{tabular}{|c|c|c|c|c|}
\hline Treatments $^{1}$ & SDM $\left(\mathrm{t} \cdot h \mathrm{~h}^{-1}\right)$ & SDM (g.plant $\left.{ }^{-1}\right)$ & SNA $\left(\mathbf{k g} \cdot h a^{-1}\right)$ & SNA (mg $\cdot$ plant $\left.^{-1}\right)$ \\
\hline \multicolumn{5}{|c|}{120 DAS } \\
\hline BR2811 & 18.99 & 43.40 & 488.40 & 1116.35 \\
\hline WN & 16.07 & 36.73 & 416.92 & 952.97 \\
\hline WON & 17.80 & 40.69 & 415.74 & 950.27 \\
\hline UFLA05-03 & 19.93 & 45.56 & 613.43 & 1402.13 \\
\hline UFLA05-09 & 20.03 & 45.78 & 697.70 & 1594.75 \\
\hline UFLA05-14 & 16.36 & 37.40 & 442.49 & 1011.40 \\
\hline \multicolumn{5}{|c|}{150 DAS } \\
\hline BR2811 & 30.95 & 70.74 & 876.83 & 2004.18 \\
\hline WN & 31.55 & 72.11 & 771.61 & 1763.68 \\
\hline WON & 20.59 & 47.07 & 620.54 & 1418.37 \\
\hline UFLA05-03 & 40.41 & 92.37 & 1293.24 & 2955.97 \\
\hline UFLA05-09 & 34.39 & 78.60 & 1095.49 & 2503.98 \\
\hline UFLA05-14 & 37.65 & 86.05 & 1186.45 & 2711.88 \\
\hline
\end{tabular}

IUFLA05-03, UFLA05-09, UFLA05-14 and BR2811: strains tested; WN: noninoculated control with mineral N (70 kg.N-urea-ha-1); W0N: noninoculated control without mineral $\mathrm{N}$.

Table 7. Contrast of mean values for shoot dry matter (SDM) of $C$. spectabilis cultivated in conventional planting area, evaluated at 60,90 , 120 and 150 DAS.

\begin{tabular}{|c|c|c|c|c|c|c|c|}
\hline \multicolumn{8}{|c|}{ Shoot dry matter (SDM) } \\
\hline \multicolumn{2}{|c|}{60 DAS } & \multicolumn{2}{|c|}{90 DAS } & \multicolumn{2}{|c|}{120 DAS } & \multicolumn{2}{|c|}{150 DAS } \\
\hline BR2811 & $W^{*}$ & BR2811 & WN & BR2811 & WN & BR2811 & WN \\
\hline BR2811 & WON & BR2811 & WON & BR2811 & WON & BR2811* & WON \\
\hline$W^{*}$ & WON & WN & WON & WN & WON & $\mathrm{WN}^{*}$ & WON \\
\hline UFLA0503* & BR2811 & U0503 & BR2811 & UFLA0503 & BR2811 & UFLA0503* & BR2811 \\
\hline UFLA0503 & $\mathrm{WN}^{*}$ & U0503 & WN & UFLA0503 & WN & UFLA0503* & WN \\
\hline UFLA0503* & WON & U0503 & WON & UFLA0503 & WON & UFLA0503* & WON \\
\hline UFLA0509 & BR2811 & U0509 & BR2811 & UFLA0509 & BR2811 & UFLA0509 & BR2811 \\
\hline UFLA0509 & $\mathrm{WN}^{*}$ & U0509 & WN & UFLA0509 & WN & UFLA0509 & WN \\
\hline UFLA0509 & WON & U0509 & WON & UFLA0509 & WON & UFLA0509* & WON \\
\hline UFLA0514 & BR2811* & U0514 & BR2811 & UFLA0514 & BR2811 & UFLA0514* & BR2811 \\
\hline UFLA0514 & $\mathrm{WN}^{*}$ & U0514 & WN & UFLA0514 & WN & UFLA0514* & WN \\
\hline UFLA0514 & WON* & U0514 & WON & UFLA0514 & WON & UFLA0514* & WON \\
\hline
\end{tabular}

The treatments are compared by pairs on the line within each analyzed variable. The presence of asteristics in the treatment represents it is significantly greater than the constrating treatment ( $\mathrm{F}$ test $[\mathrm{p}<0.05$ or $\mathrm{p}<0.10])$; ${ }^{* *}$ significant effect at $5 \%$ probability; ${ }^{*}$ significant effect at $10 \%$ probability. WN: noninoculated control with mineral $\mathrm{N}\left(70 \mathrm{~kg} \mathrm{~N}\right.$-urea ha $\left.{ }^{-1}\right)$; WON: noninoculated control without mineral $\mathrm{N}$.

In relation to the SNA variable (Tables 6 and 8) at 60 DAS, the SNA provided by the strains UFLA05-03 and UFLA05-09 was similar to those of the controls W0N and BR2811, but not exceeding that of WN. The SNA of the UFLA05-14 strain was lower than that of all the controls. The WN control was greater than the mean values of the other controls, and BR2811 was equal to the results of the W0N. In the last collection period, at 150 DAS (full flowering), all the new strains tested led to higher SNA than the W0N control; the UFLA05-03 strain also outperformed the results of the controls the BR2811 strain and of WN, whereas the UFLA05-09 and UFLA05-14 strains presented similar SNA averages of BR2811 and WN. The BR2811 was equal to WN, and both were greater than the results of W0N. 
Table 8. Contrast of mean values for shoot $\mathrm{N}$ accumulation (SNA) of $C$. spectabilis cultivated in conventional planting area, evaluated at 60 , 90,120 and 150 DAS.

\begin{tabular}{|c|c|c|c|c|c|c|c|}
\hline \multicolumn{8}{|c|}{ Shoot $\mathrm{N}$ accumulation (SNA) } \\
\hline \multicolumn{2}{|c|}{60 DAS } & \multicolumn{2}{|c|}{90 DAS } & \multicolumn{2}{|c|}{120 DAS } & \multicolumn{2}{|c|}{150 DAS } \\
\hline BR2811 & $\mathrm{WN}^{*}$ & BR2811 & WN & BR2811 & WN & BR2811 & WN \\
\hline BR2811 & WON & BR2811 & WON & BR2811 & WON & BR2811* & WON \\
\hline $\mathrm{WN}^{*}$ & WON & WN & WON & WN & WON & $\mathrm{WN}^{*}$ & WON \\
\hline UFLA0503 & BR2811 & U0503 & BR2811 & UFLA0503 & BR2811 & UFLA0503* & BR2811 \\
\hline UFLA0503 & $\mathrm{WN}^{*}$ & U0503 & WN & UFLA0503 & WN & UFLA0503* & WN \\
\hline UFLA0503 & WON & U0503 & WON & UFLA0503 & WON & UFLA0503* & WON \\
\hline UFLA0509 & BR2811 & U0509 & BR2811 & UFLA0509 & BR2811 & UFLA0509 & BR2811 \\
\hline UFLA0509 & $\mathrm{WN}^{*}$ & U0509 & WN & UFLA0509 & WN & UFLA0509 & WN \\
\hline UFLA0509 & WON & U0509 & WON & UFLA0509 & WON & UFLA0509* & WON \\
\hline UFLA0514 & BR2811* & U0514 & BR2811 & UFLA0514 & BR2811 & UFLA0514 & BR2811 \\
\hline UFLA0514 & $\mathrm{WN}^{*}$ & U0514 & WN & UFLA0514 & WN & UFLA0514 & WN \\
\hline UFLA0514 & $\mathrm{WON}^{*}$ & U0514 & WON & UFLA0514 & WON & UFLA0514* & WON \\
\hline
\end{tabular}

The treatments are compared by pairs on the line within each analyzed variable. The presence of asteristics in the treatment represents it is significantly greater than the constrating treatment ( $F$ test $[p<0.05$ or $p<0.10]$ ); ${ }^{\star \star}$ significant effect at $5 \%$ probability; ${ }^{\star}$ significant effect at $10 \%$ probability. WN: noninoculated control with mineral $\mathrm{N}\left(70 \mathrm{~kg} \cdot \mathrm{N}\right.$-urea $\left.\cdot \mathrm{ha}^{-1}\right) ; \mathrm{WON}$ : noninoculated control without mineral $\mathrm{N}$

\section{DISCUSSION}

In the soil where the experiments were set up, native LNNFB was found capable of nodulating C. spectabilis. This may be related to the edaphic and climatic conditions that allowed them to establish themselves and survive. The mean density $\left(2.5 \times 10^{3}\right.$ cells per gram of soil) obtained in the current study is within the range found in other studies with promiscuous grain legumes (Oliveira et al. 2019; Soares et al. $2006 \mathrm{a}, \mathrm{b}$ ) and with pigeon pea, a species also used as a green manure crop (Rufini et al. 2016) in the same region as the experimental area.

As already explained, in greenhouse evaluations for the collection made at 60 DAS, there was a significant difference among the treatments for the NDM, SDM and SNA variables, which did not occur in the evaluations made at 140 DAS. The results of the last collection may have been affected by space limitations for the roots due to the dimensions of the pots. Although the plants were well developed, it was necessary to wait for them to reach the flowering stage to perform the evaluation. If it was not for the limitation of space for plant development, good results would likely have been observed in the second collection since good performance of the strains was observed in the field in a similar period.

The strains UFLA05-03, UFLA05-09, and UFLA05-14 provided high SDM and SNA production in the field, in the collection made at 150 DAS (flowering); their results were superior to those of the native LNNFB, and even superior or equal to those of the control with mineral $\mathrm{N}$ and of the reference strain BR2811. These results indicate that these strains have high BNF efficiency when inoculated on C. spectabilis, mainly the strain UFLA05-03. Therefore, they have the potential to be used in the production of inoculants for C. spectabilis; however, new tests are recommended in different edaphoclimatic conditions.

The strains UFLA05-03, UFLA05-09 and UFLA05-14 also showed high symbiotic efficiency with C. spectabilis in studies in pots with sterilized nutrient solution (Rangel et al. 2017). These strains, which were isolated from nodules of the plant species itself present in an area contaminated with arsenic (gold mining area), had dry matter weight and shoot $\mathrm{N}$ accumulation higher than or equal to that of the control with mineral $\mathrm{N}$ and the strain approved as an inoculant, BR2811. The authors concluded that these strains had biotechnological potential and suggested confirmation of their efficiency under more complex growing conditions, such as those carried out in this study.

When each treatment is evaluated separately, an increase is found in SDM and in SNA over time, i.e., the quantity of dry matter produced, as well as the $\mathrm{N}$ accumulated in this material, increases at each collection made, reaching the maximum values at flowering. There are advantages in growing this green manure crop for this period of time, which, although it 
is long, would avoid infestation of the area by C. spectabilis due to seed dispersal after fructification. In addition, in this period, the three strains tested and also BR2811 showed efficiency in symbiosis with C. spectabilis. The contribution of the BNF promoted by C. spectabilis had also been shown by the ${ }^{15} \mathrm{~N}$ technique. Mendonça et al. (2017) evaluated N levels in leaves of coffee intercropped with species of green manure crops. The results showed that the total $\mathrm{N}$ accumulation by C. spectabilis was $93.42 \mathrm{~kg} \cdot \mathrm{ha}^{-1}$, of which $34.1 \mathrm{~kg} \cdot \mathrm{ha}^{-1}$ was derived from BNF, which, in turn, contributed approximately $50 \%$ of the $\mathrm{N}$ transferred to the coffee plant. Thus, the authors concluded that C. spectabilis is a leguminous crop with high potential for transferring $\mathrm{N}$ to the coffee plant and recommended its use in intercropping with coffee. Considering that the seeds of C. spectabilis were not inoculated and that fertilization through the soil likely inhibited the action of native LNNFB, there is reason to believe that even better results could have been obtained with the use of efficient strains.

The results of SNA of the native LNNFB indicate that they were efficient in BNF up to the 120 DAS. However, a LNNFB community efficient in BNF is not always the rule under the diverse edaphic and climatic conditions in Brazil. Resende et al. (2003) estimated that BNF contributed $16 \mathrm{~kg} \cdot \mathrm{ha}^{-1}$ of $\mathrm{N}$ to the biomass of C. spectabilis grown for 71 days, but these plants had not been inoculated with LNNFB of proven efficiency. It can therefore be concluded that the BNF occurring through the native community present in the soil presented low efficiency when compared to the results obtained in this study by the new strains. This comparison shows the importance of ensuring the inoculation of the green manure crop with strains of proven efficiency, since an efficient native community cannot always be relied upon.

According to the results obtained in this study, the inoculation with efficient strains did not increase the development of the plants in the evaluations that preceded the flowering, not interfering in the cut period of the plants since they did not differ from the WON, WN and BR2811 controls. This was probably due to the very low precipitation during this period (Fig. 1). However, ensuring the inoculation of the green manure crop with strains of proven efficiency is necessary since the soils do not always have efficient native LNNFB. In addition, the practicality and the low cost of inoculation should also be considered. Thus, the results of the present study show that the strains tested (mainly UFLA05-03) are efficient in BNF and promote the growth of C. spectabilis, and the practice of inoculating this species is recommended for enriching its shoots in $\mathrm{N}$ especially at flowering.

\section{CONCLUSION}

The greatest gains in the development and nutrition of plants using the new strains were obtained in flowering at the field experiment.

All the new strains tested, as well as BR2811, were efficient in fixing $\mathrm{N}_{2}$ in C. spectabilis. However, inoculation of C. spectabilis seeds with the UFLA05-03 strain is a real alternative for increasing production of biomass enriched with $\mathrm{N}$ to serve as a green manure crop and more tests must be developed with a view to its approval as inoculant by MAPA.

\section{AUTHORS' CONTRIBUTION}

Conceptualization: Silva J. S., Oliveira D. P., Rufini M. and Moreira F. M. S.; Formal Analysis: Silva J. S. and Oliveira D. P.; Funding Acquisition: Moreira F. M. S.; Investigation: Silva J. S., Oliveira D. P., Rufini M., Silva C. L., Baptista M. V. D. G. B., Silva L. C., Aragão O. O. S. and Pereira T. A.; Methodology: Silva J. S., Oliveira D. P., Rufini M. and Moreira F. M. S.; Project Administration: Silva J. S. and Moreira F. M. S.; Supervision: Moreira F. M. S.; Visualization: Silva J. S., Oliveira D. P. and Aragão O. O. S.; Writing - Original Draft: Silva J. S., Oliveira D. P., Rufini M. and Moreira F. M. S.; Writing Review and Editing: Silva J. S., Oliveira D. P., Rufini M. and Moreira F. M. S.

\section{DATA AVAILABILITY STATEMENT}

Data will be available upon request. 


\section{FUNDING}

Coordenação de Aperfeiçoamento de Pessoal de Nível Superior

https://doi.org/10.13039/501100002322

Grant No. 583/2018 PROEX

Conselho Nacional de Desenvolvimento Científico e Tecnológico

https://doi.org/10.13039/501100003593

Grant No. 304527/2016-5 and 431504/2016-4

Fundação de Amparo à Pesquisa do Estado de Minas Gerais

https://doi.org/10.13039/501100004901

Grant No. CAG - RED-00330-16

\section{ACKNOWLEDGMENTS}

This research is associated with the Brazilian National Institute of Science and Technology (Soil Biodiversity/INCT - CNPq).

\section{REFERENCES}

Aita, C., Basso, C. J., Ceretta, C. A., Gonçalves, C. N. and Da Ros, C. O. (2001). Plantas de cobertura de solo como fonte de nitrogênio ao milho. Revista Brasileira de Ciência do Solo, 25, 157-165. https://doi.org/10.1590/S0100-06832001000100017

Aita, C. and Giacomini, S. J. (2003). Decomposição e liberação de nitrogênio de resíduos culturais de plantas de cobertura de solo solteiras e consorciadas. Revista Brasileira de Ciência do Solo, 27, 601-612. https://doi.org/10.1590/S0100-06832003000400004

Albuquerque, A. W., Santos, J. R., Moura Filho, G. and Reis L. S. (2013). Plantas de cobertura e adubação nitrogenada na produção de milho em sistema de plantio direto. Revista Brasileira de Engenharia Agrícola e Ambiental, 17, 721-726. https://doi.org/10.1590/ S1415-43662013000700005

Alvarez, V. V. H., Novais, R. F., Barros, N. F., Cantarutti, R. B. and Lopes A. S. (1999). Interpretação dos resultados das análises de solos. In A. C. Ribeiro, P. T. G. Guimarães and V. V. H. Alvarez (Eds.), Recomendações para uso de corretivos e fertilizantes em Minas Gerais 5a Aproximação (p.25-32). Viçosa: SBCS.

[Brazil]. Ministério da Agricultura, Pecuária e Abastecimento. (2011). Instrução normativa nº 13, de 24 de março de 2011. Anexo protocolo oficial para avaliação da viabilidade e eficiência agronômica de cepas, inoculantes e tecnologias relacionados ao processo de fixação biológica do nitrogênio em leguminosas. Brasília: Diário Oficial da União.

Döbereiner, J., Baldani, V. L. D. and Baldani, J. I. (1995). Como isolar e identificar bactérias diazotróficas de plantas não-leguminosas. Brasília: Embrapa. Chapter 4, Contagem de microorganismos diazotróficos; p. 39-42.

Florentino, L. A., Rezende, A. V., Mesquita, A. C., Lima, A. R. S., Marques, D. J. and Miranda, J. M. (2014). Diversidade e potencial de utilização dos rizóbios isolados de nódulos de Gliricidia sepium. Revista de Ciências Agrárias, 37, 320-328.

Hoagland, D. R. and Arnon, D. I. (1950). The water-culture method for growing plants without soil. Berkeley: Agricultural Experiment Station. Malavolta, E., Vitti, G. C. and Oliveira, S. A. (1989). Avaliação do Estado Nutricional das Plantas: Princípiose Aplicações. Piracicaba: Potafos. 
Mendonça, E. S., Lima, P. C., Guimarães G. P., Moura, G. P., Melo, W. and Andrade, F. V. (2017). Biological Nitrogen Fixation by Legumes and N Uptake by Coffee Plants. Revista Brasileira de Ciência do Solo, 41, e0160178. https://doi.org/10.1590/18069657rbcs20160178

Mercante, F. M., Hungria, M., Mendes, I. C., Reis Júnior, F. B. and Diva S. A. (2014). Fixação biológica de nitrogênio em adubos verdes. In O. F. Lima Filho, E. J. Ambrosano, F. Rossi and J. A. D. Carlos (Eds.), Adubação verde e plantas de cobertura no Brasil - Fundamentos e Prática (p. 307-334). Brasília: Embrapa.

Moreira, F. M. S. and Siqueira, J. O. (2006). Microbiologia e Bioquímica do Solo. Lavras: UFLA.

Nogueira, C. H. P., Correia, N. M., Gomes, L. J. P. and Ferreira, P. S. H. (2019). Selectivity of bentazon and nicosulfuron in Crotalaria spectabilis intercropped with maize culture. Revista Caatinga, 32, 381-389. https://doi.org/10.1590/1983-21252019v32n211rc

Oliveira, D. P., Pereira, T. A., Rufini, M., Martins, F. A. D., Silva Junior, C. L., Baptista, M. V. B. D. G., Silva, J. S., Oliveira, P. A. C., Aragão, O. O. S., Andrade, M. J. B. and Moreira. F. M. S. (2019). Liquid Inoculation with Rhizobia in the Planting Furrow of Common Bean under No Till Is Feasible under Different Soil and Climatic Conditions. Crop Science, 59, 2178-2184. https://doi.org/10.2135/cropsci2018.08.0522

Peche Filho, A., Ambrosano, E. J. and Luz, P. H. C. (2014). Espécies de adubos verdes e plantas de cobertura e recomendações para seu uso. In O. F. Lima Filho, E. J. Ambrosano, F. Rossi and J. A. D. Carlos (Eds.), Adubação Verde e Plantas de Cobertura no Brasil: Fundamentos e Prática. (p. 61-167). Brasília: Embrapa.

Rangel, W. M., Longatti, S. M. O., Ferreira, P. A. A., Bonaldi, D. S., Guimarães, A. A., Thijs, S., Weyens, N., Vangronsveld, J. and Moreira, F. M. S. (2017). Leguminosae native nodulating bacteria from a gold mine As-contaminated soil: Multi-resistance to trace elements, and possible role in plant growth and mineral nutrition. International Journal of Phytoremediation, 19, 925-936. https://doi.org/10.1080/152 26514.2017.1303812

R Development Core Team. (2019). R: A language and environment for statistical computing. Vienna: R Foundation for Statistical Computing.

Resende, A. S., Xavier, R. P., Quesada, D. M., Urquiaga, S., Alves, B. J. R. and Boddey, R. M. (2003). Use of green manures in increasing inputs of biologically fixed nitrogen to sugar cane. Biology and Fertility of Soils, 37, 215-220. https://doi.org/10.1007/s00374-003-0585-6

Rufini, M., Oliveira, D. P., Trochmann, A., Soares, B. L., Andrade, M. J. B. and Moreira, F. M. S. (2016). Bradyrhizobium spp. Strains in Symbiosis with Pigeon Pea cv. Fava-Larga under Greenhouse and Field Conditions. Revista Brasileira de Ciência do Solo, 40, :e0160156. https://doi.org/10.1590/18069657rbcs20160156

Sarruge, J. R. and Haag, H. P. (1979). Análises químicas em plantas. Boletim técnico. Piracicaba: ESALQ.

Soares, A. L. L., Ferreira, P. A. A., Pereira, J. P. A. R., Vale, H. M. M., Lima, A. S., Andrade, M. J. B. and Moreira, F. M. S. (2006 a). Eficiência agronômica de rizóbios selecionados e diversidade de populações nativas nodulíferas em Perdões (MG). II-feijoeiro. Revista Brasileira de Ciência do Solo, 30, 803-811. https://doi.org/10.1590/S0100-06832006000500006

Soares, A. L. L., Pereira, J. P. A. R., Ferreira, P. A. A., Vale, H. M. M., Lima, A. S., Andrade, M. J. B. and Moreira. F. M. S. (2006 b). Eficiência agronômica de rizóbios selecionados e diversidade de populações nativas nodulíferas em Perdões (MG). I - caupi. Revista Brasileira de Ciência do Solo, 30, 795-802. https://doi.org/10.1590/S0100-06832006000500005

Souza, E. D., Carneiro, M. A. C. and Banys, V. L. (2008). Fitomassa e acúmulo de nitrogênio, em espécies vegetais de cobertura do solo para um Latossolo Vermelho distroférrico de Cerrado. Acta Scientiarum Agronomy, 30, 525-531. https://doi.org/10.4025/actasciagron. v30i4.5313

Tenelli, S., Otto, R., Castro, S. A. Q., Sánchez, C. E. B., Sattolo, T. M. S., Kamogawa, M. Y., Pagliari, P. H. and Carvalho. J. L. N. (2019). Legume nitrogen credits for sugarcane production: implications for soil $\mathrm{N}$ availability and ratoon yield. Nutrient Cycling in Agroecosystems, 113 , 307-322. https://doi.org/10.1007/s10705-019-09979-y 